\title{
FAKTOR-FAKTOR YANG MEMPENGARUHI PERILAKU PETANI DALAM MENERIMA OPERASI PANGAN RIAU MAKMUR DI SEMBILAN KABUPATEN SE-PROVINSI RIAU
}

\author{
Nuke Fatmasari ${ }^{1}$, Fajar Restuhadi ${ }^{2}$ dan Roza Yulida $^{3}$ \\ ${ }^{1)}$ Mahasiswa Jurusan Agribisnis Fakultas Pertanian Universitas Riau \\ ${ }^{2)}{ }^{3)}$ Staf Pengajar Jurusan Agribisnis Fakultas Pertanian Universitas Riau \\ Email : juvesar@gmail.com
}

\begin{abstract}
The concept of the factors that influence the behavior of farmers in receiving Operasi Pangan Riau Makmur program (OPRM) needs to be done to determine the most significant effect on the program's accepting. The designing of a model before the implementation of a program, is expected to minimize the unusable things in reality. Modeling analysis SEM (structural equation model) which is used in behavior of farmer's research designed so as to find a suitable model. Three exogenous variables used in this research, the characteristics of farmers, extension of competence, and competence of the management of farmer groups. Each of these exogenous variables formed by eight indicators, so it is could explain that the skills, systematic program delivery, mastery of the program, and time management, are not included in the indicator models that is affecting the behavior of farmers as endogenous variables, to accept or deny the existence of the program. Farmer behavior is further analyzed the suitability of the model with the independence of farmers. Suitability models were constructed and analyzed is expected to be used by the government or related agencies, before involving the farmers as participants.
\end{abstract}

Keywords: Farmer's behavior, Structural Equation Model, OPRM

\begin{abstract}
Abstrak: Pemahaman terhadap faktor-faktor yang memengaruhi perilaku petani dalam menerima program Operasi Pangan Riau Makmur (OPRM) perlu dilakukan untuk mengetahui pengaruh paling signifikan terhadap penerimaan program. Dirancangnya model sebelum penyelenggaraan suatu program, diharapkan dapat meminimalisir realisasi lapangan yang sia-sia.Analisis permodelan SEM (structural equation model) yang digunakan di penelitian perilaku petani dirancang sedemikian rupa untuk menemukan model yang sesuai.Tiga variabel eksogen dipergunakan dalam penelitian, yakni karakteristik petani, kompetensi penyuluh, dan kompetensi pengurus kelompok tani. Masing-masing variabel eksogen dibentuk oleh delapan indikator, sehingga diketahui bahwa keterampilan, sistematis dalam penyampaian program, penguasaan materi program, serta mampu mengefisiensi waktu, adalah tidak termasuk ke dalam indikator model yang membentuk perilaku petani selaku variabel endogen, untuk menerima atau menolak keberadaan program. Perilaku petani ini selanjutnya dianalisis kesesuaian modelnya dengan kemandirian petani.Sesuainya model yang dibangun dan dianalisis diharapkan dapat dipergunakan oleh pemerintah atau instansi terkait, sebelum merealisasikan program yang melibatkan petani sebagai peserta.
\end{abstract}

Kata Kunci : Perilaku Petani, Structural Equation Model, OPRM

\section{PENDAHULUAN}

Pemerintah Provinsi Riau melalui Dinas Tanaman Pangan dan Hortikultura Provinsi
Riau telah selesai melaksanakan kegiatan Operasi Pangan Riau Makmur (OPRM), melibatkan 524 kelompok tani di 9 kabupaten se Provinsi Riau, dari tahun 2009 hingga tahun 
2013. OPRM bertujuan untuk menjaga stabilitas tanaman pangan sehingga impor beras ke wilayah Provinsi Riau dapat ditekan.

Data Badan Pusat Statistik 2014 menjabarkan perkembangan produksi padi periode bulan Januari hingga bulan Desember, dari tahun 2012 sampai tahun 2013,justru turun hingga 25.497 hektare atau sekitar 17,70 persen. Penurunan luas panen kembali terjadi untuk periode waktu bulan Januari hingga bulan Desember, daritahun 2013 sampai dengan tahun 2014 , yakni sebesar 10,04 persen atau sekitar 11.901 hektare.

Bank Indonesia dalam data kajian ekonomi regional tahun 2014, jugamemaparkan hal yang sama, di mana untuk periode bulan Mei hingga bulan Agustus 2014, perkembangan produksi padi turun sebesar 17,01 persen (year on year/yoy) atau hanya mampu mencapai 137.136 ton.Penurunan produksi beras yang terus terjadi melatar belakangi keingin tahuan peneliti untuk melihat perilaku petani di 9 kabupaten se Riau terhadap program OPRM yang menelan anggaran sekitar Rp2,1 triliun tersebut (Laporan Dinas Tanaman Pangan dan Hortikultura dalam Buku OPRM tahun 2013).

Sembilan kabupaten yang terlibat dalam pelaksanaan OPRM adalah Kabupaten Kampar, Kabupaten Rokanhulu, Kabupaten Pelalawan, Kabupaten Bengkalis, Kabupaten Kuantansingingi, Kabupaten Siak, Kabupaten Rokanhilir, Kabupaten Indragirihilir dan Kabupaten Indragirihulu.

Di 9 kabupaten tersebut dilaksanakan tiga kegiatan yang menjadi sasaran utama dari OPRM, yakni meningkatkan produktivitas tanaman padi dari panen 1 kali setahun menjadi 2 kali setahun atau dikenal dengan peningkatan Indeks Pertanaman (IP) 100 ke IP 200 untuk luas areal tanam 68.108,18 hektare, Rehabilitasi Sawah Terlantar (RST) untuk luas arel tanam 13.126,85 hektare, dan Cetak Sawah Baru (CSB)untuk lahan areal tanam seluas 18.765 hektare.

Petani memiliki perilaku yang berbedabeda dalam melaksanakan OPRM. Petani kabupaten Indragirihilir dinyatakan mampu meraih predikat pencapaian tertinggi untuk IP 100 ke IP 200, yakni 12.707 hektare luas areal tanam. Petani kabupaten Pelalawan pun berhasil meraih peraih pencapaian RST dan CSB tertinggi, yakni 926 hektare untuk program RST, dan 2.753 hektare untuk program CSB. Perilaku petani secara keseluruhan diduga akan mempengaruhi keikut-sertaan mereka dalam program OPRM. Apalagi menurut Andrianto (2014), petani cenderung bersikap kolot dan menolak perubahan.Perilaku petani umumnya selalu melakukan cara-cara yang biasa dilakukan oleh para pendahulu mereka (Andrianto, 2014).

Banyak faktor yang peneliti duga akan mempengaruhi perilaku pertani dalam menerima atau menolak program OPRM. Karakteristik dari penerima manfaat pun harus dicermati saat menerapkan suatu program, khususnya program pemberdayaan masyarakat (Mardikanto dan Soebianto, 2013). Karakteristik petani yang selalu diukur dalam penelitiian perilaku adalah umur, pendidikan formal, luas usaha tani, pengalaman, keterampilan, motivasi berusaha, modal usaha tani dan kemampuan bertahan atau tingkat subsitensi (Adi Putra, 2012).

Karakteristik dari penyuluh, terdiri dari kemampuan berkomunikasi, daya adaptasi, sistematis dalam penyampaian program, kemauan untuk memahami keinginan petani, penguasaan terhadap materi program, pengalaman, kemampuan untuk mengefisiensi waktu serta kemauan memberi dukungan semangat kepada petani, juga diduga sebagai faktor-faktor yang akan mempengaruhi perilaku petani. Demikian pula dengan kompetensi pengurus kelompok tani, seperti kemampuan menyebarluaskan informasi, memberi contoh, menyarankan pelaksanaan program, mempengaruhi anggota kelompok, memberi semangat, selalu bersikap jujur dan terbuka, serta selalu melibatkan anggota dalam pengambilan keputusan.

Semua faktor-faktor ini diukur untuk melihat perilaku petani untuk mengangap program OPRM lebih baik dari program bercocok tanam padi konvensional, mampu memberikan banyak keuntungan, tidak sulit untuk dilaksanakan, tidak mengandung risiko, sesuai dengan kebiasaan masyarakat tani dan dapat meningkatkan produktivitas usaha tani. Setelah itu baru diukur kemandirian petani memutuskan untuk ikut serta dalam program, yang mana kemandirian inidapat diukur dari kemampuan petani bekerja sama dengan pedagang, bekerja sama dengan penyuluh, cepat dalam mengakses informasi, mampu 
mengambil suatu keputusan, memiliki akses ke kredit usaha tani serta mampu mempersiapkan modal usaha tani.

Karakteristik petani, kompetensi penyuluh, dan kompetensi pengurus kelompok tani diduga sebagai faktor-faktor yang akan mempengaruhi perilaku petani. Sementara perilaku petani menentukan kemandirian petani untuk menerima atau menolak program OPRM.

\section{METODE PENELITIAN}

\section{Data dan Sumber Data}

Peneliti menggunakan data primer dari 225 petani yang dikumpulkan di Kabupaten Indragiri Hilir, Indragiri Hulu, Rokanhulu, Rokanhilir, Pelalawan, Siak, Kampar, Kuantansingingi dan Bengkalis, untuk periode waktu 18 Februari 2015 hingga 30 Maret 2015.

\section{Metode Analisis Data}

Data dikumpulkan melalui penyebaran kuisioner. Peneliti menggunakan skala likert atau skala sikap dengan rentang 1-7, di mana 1 = sangat tidak setuju sekali, 2 = sangat tidak setuju, $3=$ tidak setuju, $4=$ ragu-ragu, $5=$ setuju, $6=$ sangat setuju, dan $7=$ sangat setuju sekali, sebagai skala pengukuran. Sebelum dianalisis, data ordinal yang terkumpul ditransformasi ke dalam data interval menggunakan metode MSI atau Method of Successive Interval (Latan, 2013).
Peneliti menguji kesesuaian data dengan model Structural Equation Model (SEM) yang telah dibangun untuk menjelaskan varian dan korelasi antar peubah-peubah yang diobservasi (observe), dalam suatu sistem sebab akibat (kasual), dari faktor-faktor yang tidak diobservasi (unobserve).

\section{Kerangka Hipotetik}

Kerangka hipotetik yang mengambarkan model pengadopsian OPRM oleh petani di 9 kabupaten se-Riau sebagai berikut :

$$
\begin{aligned}
& \eta 1=\gamma_{1} \xi_{1}+\gamma_{2} \xi_{2}+\gamma_{3} \xi_{3}+\zeta_{1} \\
& \eta 2=\beta 1 . \eta 1+\zeta_{2}
\end{aligned}
$$

Di mana

$\xi_{1}=$ karakteristik petani $/ \mathrm{x}_{1}$

$\xi_{2}=$ kompetensi penyuluh $/ \mathrm{x}_{2}$

$\xi_{3}=$ kompetensi pengurus kelompok tani $/ \mathrm{x}_{3}$

$\zeta_{1}=$ error 1

$\zeta_{2}=$ error 2

$\eta_{1}=$ perilaku petani dalam mengambil keputusan/y

$\eta_{2}=$ kemandirian petani $/ \mathrm{z}$

$\beta 1=$ nilai satuan perilaku petani

Model awal menentukan permodelan SEM untuk melihat pengaruh langsung dan tidak langsung dari sebaran peubah laten eksogen serta peubah laten endogen seperti Gambar 1. Permodelan SEM dibangun dari beragam peubah dan indikator yang selanjutnya dijabarkan di Tabel 1.

\section{Model SEM}

Model awal yang peneliti rancang adalah :

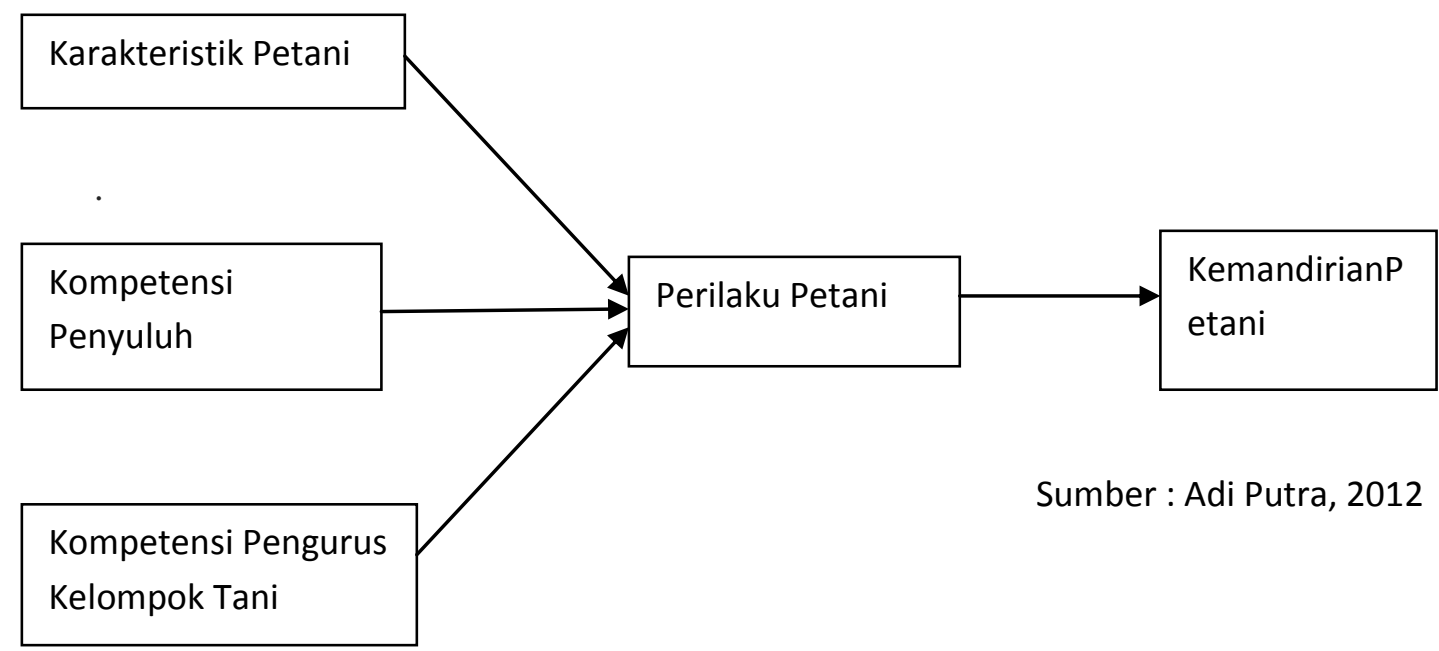




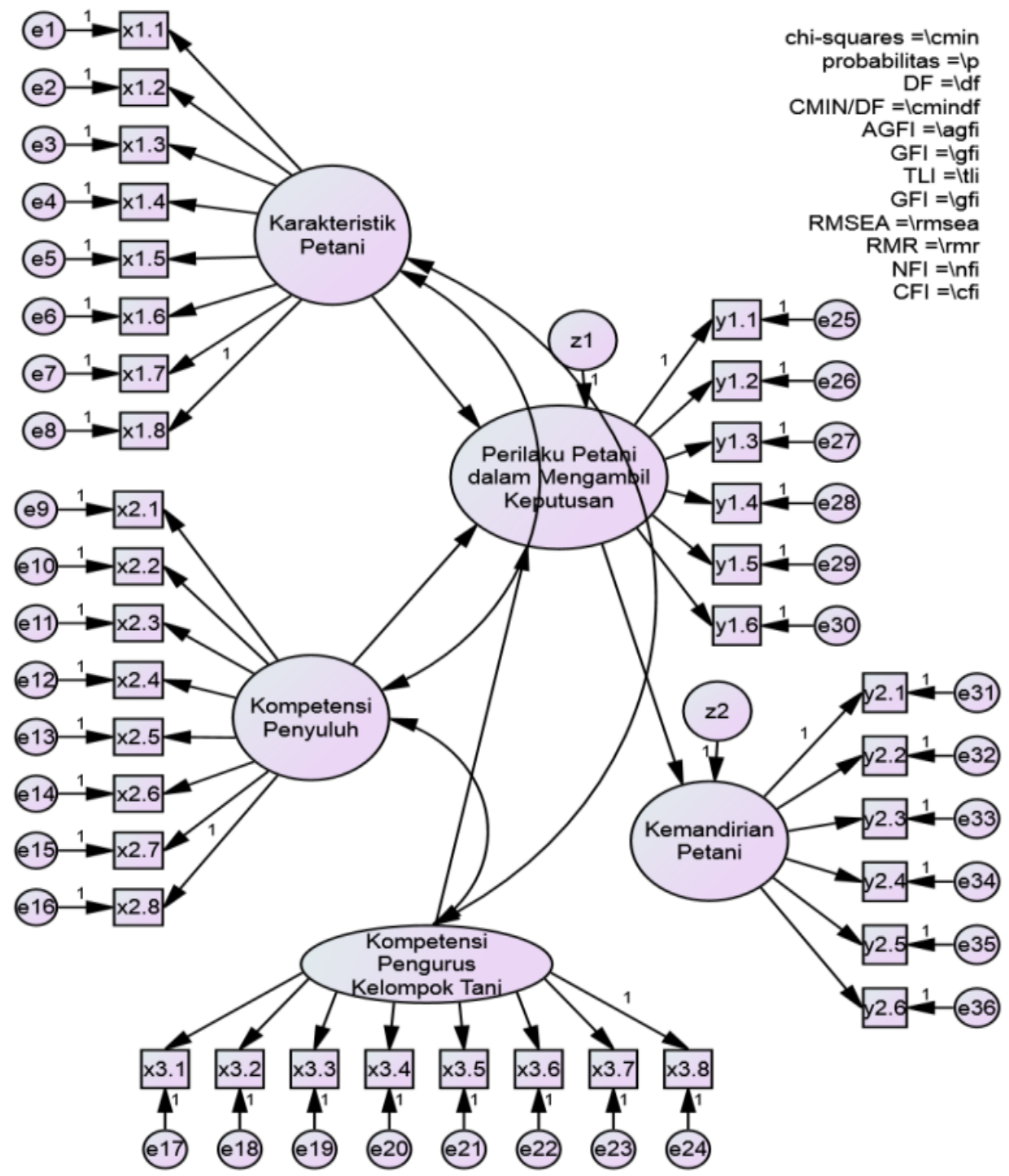

Gambar 1. Pemodelan SEM yang dipergunakan dalam penelitian.

\section{Persyaratan Model SEM}

Permodelan SEM yang dibangun dapat dinyatakan fix apabila model telah mampu memenuhi persyaratan yang ditentukan. Antara lain :

1. Data harus terdistribusi normal, di mana nilai c.r (critical ratio) multivatiate harus $2,58<\mathrm{c} . \mathrm{r}>2,58$ (Haryono dan Wardoyo, 2012).

2. Model harus valid melalui uji validitas pada program SPSS. Variabel dinyatakan valid bila nilai $\mathrm{r}$ atau koefisien korelasi $>5$ (Latan, 2013).

3. Uji reabilitas untuk melihat nilai dari indikator setiap konstruk yang dapat menggambarkan konstruk. Nilai reabilitas yang disyaratkan adalah $\geq 7$ (Latan, 2013).

4. Uji outlier multivariate, dilakukan dengan cara melihat jarak mahalanobis dari setiap indikator. Jarak mahalanobis dihitung menggunakan program excel dengan cara $=\operatorname{chiinv}(0.001,36)$ untuk $\mathrm{p}<0.001$ pada indikator 36. Nilai mahalanobis untuk penelitian ini adalah 67.98517, sehingga sampel dengan nilai di atas nilai mahalanobis, disebut sebagai sampel yang outlier multivariate (Haryono dan Wardoyo, 2012).

5. Analisis faktor konfirmatori atau CFA (confirmantory factor analysis) untuk 
menguji dimensional suatu konstruk dan variable yang dilakukan untuk satu faktor konfirmantori, dalam hal ini $\mathrm{x} 1, \mathrm{x} 2, \mathrm{x} 3, \mathrm{y}$ dan $\mathrm{z}$, serta dua faktor konfirmantori $\mathrm{x}$ dengan $\mathrm{y}$, $\mathrm{x}$ dengan $\mathrm{z}$ atau $\mathrm{y}$ dengan $\mathrm{z}$ (Haryono dan Wardoyo, 2012).
6. Setelah itu baru model yang dibangun diuji kelayakan dari model dengan melihatchi square ( $\mathrm{x}^{2}$ test), RMSEA,GFI, AGFI, TLI, NFI dan CFI yang nilainmya $0,080 \leq$ atau $<0,90$ untuk model marginal fit (Haryono dan Wardoyo, 2012).

Tabel 1. Peubah Dan Indikator Peubah Dalam Penelitian OPRM

\begin{tabular}{|c|c|c|c|}
\hline No & Peubah & Indikator & Notasi \\
\hline \multirow[t]{8}{*}{1.} & \multirow{8}{*}{ Karakteristik Petani } & Umur & $\mathrm{X}_{1.1}$ \\
\hline & & Pendidikan Formal & $\mathrm{X}_{1.2}$ \\
\hline & & Luas Usaha Tani & $\mathrm{X}_{1.3}$ \\
\hline & & Pengalaman & $\mathrm{X}_{1.4}$ \\
\hline & & Keterampilan & $\mathrm{X}_{1.5}$ \\
\hline & & Motivasi Berusaha & $\mathrm{X}_{1.6}$ \\
\hline & & Modal Usaha Tani & $\mathrm{X}_{1.7}$ \\
\hline & & Tingkat Subsitensi & $\mathrm{X}_{1.8}$ \\
\hline \multirow[t]{8}{*}{2.} & \multirow[t]{8}{*}{ Kompetensi Penyuluh } & Kemampuan berkomunikasi & $\mathrm{X}_{2.1}$ \\
\hline & & Daya adaptasi & $\mathrm{X}_{2.2}$ \\
\hline & & Sistematis dalam penyampaian program & $\mathrm{X}_{2.3}$ \\
\hline & & Memahami keinginan petani & $\mathrm{X}_{2.4}$ \\
\hline & & Penguasaan materi program & $\mathrm{X}_{2.5}$ \\
\hline & & Berpengalaman & $\mathrm{X}_{2.6}$ \\
\hline & & Mampu mengefisiensi waktu & $\mathrm{X}_{2.7}$ \\
\hline & & $\begin{array}{l}\text { Mau memberi dukungan semangat pada } \\
\text { masyarakat tani }\end{array}$ & $\mathrm{X}_{2.8}$ \\
\hline \multirow[t]{8}{*}{3.} & \multirow[t]{8}{*}{$\begin{array}{l}\text { Kompetensi Pengurus } \\
\text { Kelompok Tani }\end{array}$} & $\begin{array}{l}\text { Kemampuan dalam menyebarluaskan } \\
\text { informasi }\end{array}$ & $\mathrm{X}_{3.1}$ \\
\hline & & Mau memberikan contoh & $\mathrm{X}_{3.2}$ \\
\hline & & Menyarankan pelaksanaan program & $\mathrm{X}_{3.3}$ \\
\hline & & Memengaruhi anggota kelompok & $\mathrm{X}_{3.4}$ \\
\hline & & Mau memberikan semangat & $\mathrm{X}_{3.5}$ \\
\hline & & $\begin{array}{l}\text { Memiliki pengetahuan dan wawasan yang } \\
\text { luas tentang OPRM }\end{array}$ & $\mathrm{X}_{3.6}$ \\
\hline & & Selalu bersikap jujur dan terbuka & $\mathrm{X}_{3.7}$ \\
\hline & & Selalu melibatkan anggota dalam & $\mathrm{X}_{3.8}$ \\
\hline \multirow[t]{6}{*}{4.} & \multirow{6}{*}{$\begin{array}{l}\text { Perilaku petani dalam } \\
\text { pengambilan keputusan }\end{array}$} & pengambilan keputusan & \\
\hline & & $\begin{array}{l}\text { OPRM lebih baik dari bercocok tanam padi } \\
\text { konvesional }\end{array}$ & $\mathrm{Y}_{1.1}$ \\
\hline & & Mampu memberikan banyak keuntungan & $\mathrm{Y}_{1.2}$ \\
\hline & & Tidak sulit untuk dilaksanakan & $\mathrm{Y}_{1.3}$ \\
\hline & & Tidak berisiko & $\mathrm{Y}_{1.4}$ \\
\hline & & Sesuai dengan kebiasaan masyarakat tani & $\mathrm{Y}_{1.5}$ \\
\hline \multirow[t]{8}{*}{5.} & \multirow[t]{8}{*}{ Kemandirian petani } & Dapat meningkatkan produktivitas usaha tani & $\mathrm{Y}_{1.6}$ \\
\hline & & $\begin{array}{l}\text { Kemampuannya bekerja sama dengan } \\
\text { pedagang }\end{array}$ & $\mathrm{Z}_{1.1}$ \\
\hline & & $\begin{array}{l}\text { Kemampuannya bekerja sama dengan } \\
\text { penyuluh }\end{array}$ & $\mathrm{Z}_{12}$ \\
\hline & & Cepat dalam mengambil informasi & \\
\hline & & Mampu mengambil keputusan & $\mathrm{Z}_{1.3}$ \\
\hline & & Memiliki akses ke kredit usaha tani & $\mathrm{Z}_{1.4}$ \\
\hline & & Mampu menyiapkan modal usaha tani & $\mathrm{Z}_{1.5}$ \\
\hline & & & $\mathrm{Z}_{1.6}$ \\
\hline
\end{tabular}


Nuke F., Fajar R. Dan Roza Y. : Faktor-Faktor Yang Mempengaruhi Perilaku Petani ...

\section{Analisis Faktor}

Peneliti melakukan analisis faktor untuk melihat kesesuaian dari kerangka penelitian yang telah dibangun. Pengujian analisis faktor dilaksanakan untuk mengetahui kebenaran dari penempatan masing-masing indikator. Analisis faktor ini dilakukan dengan program SPSS.

\section{HASIL DAN PEMBAHASAN}

Permodelan SEM semula dibangun dengan melibatkan semua konstruk yang dirancang di awal penelitian seperti gambar 2 .

Permodelan SEM yang melibatkan semua indikator diketahui belum memenuhi syarat uji kelayakan sebuah model, dan mengandung hubungan yang negatif, yakni antara $\mathrm{Y}$ dan $\mathrm{Z}$, di mana kemandirian petani dipengaruhi $-0,57$ satuan perilaku petani. Hasil estimasi keseluruhan dari permodelan ini dapat dilihat pada tabel 2.

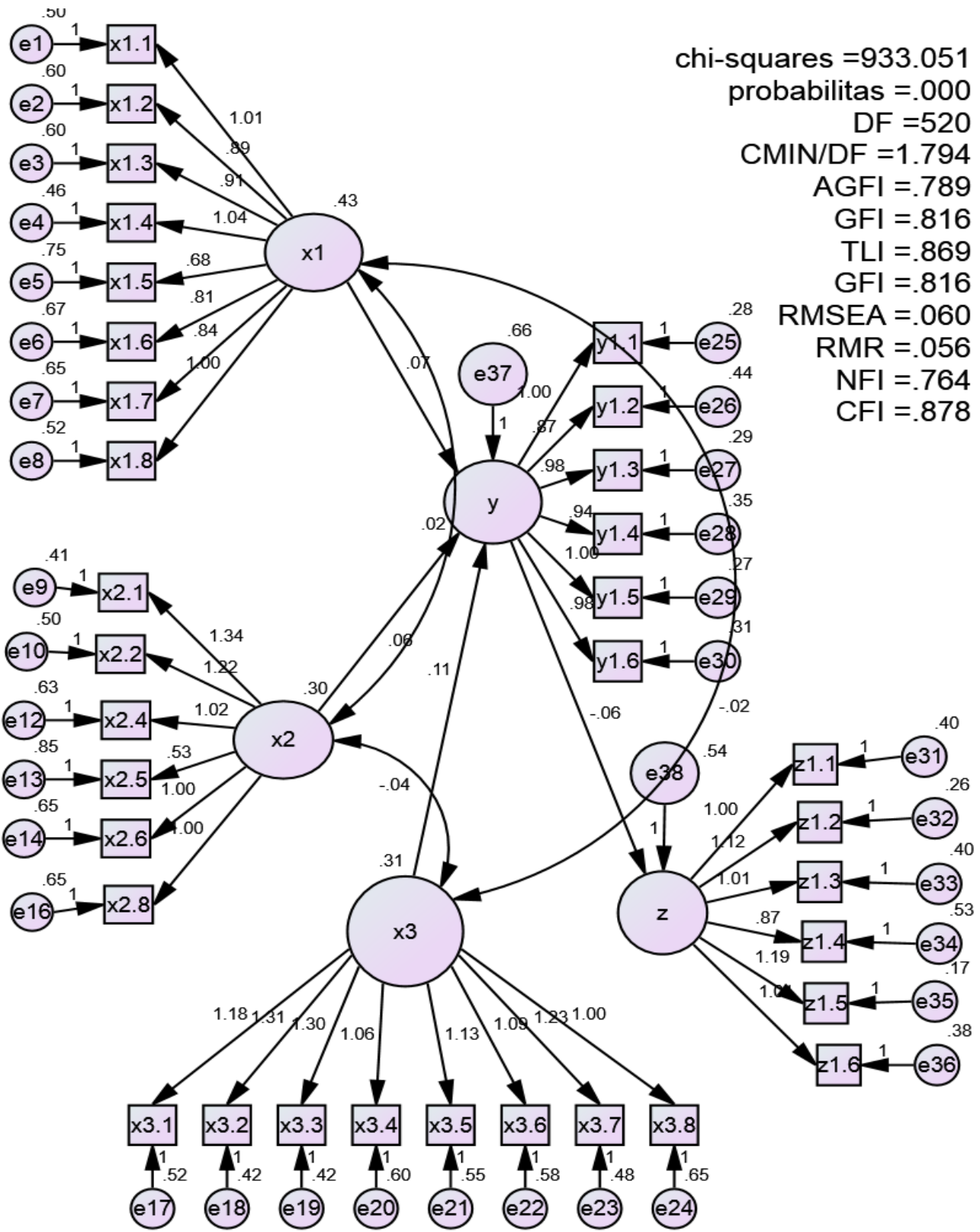

Gambar 2. Permodelan SEM Melibatkan Semua Indikator 
Nuke F., Fajar R. Dan Roza Y. : Faktor-Faktor Yang Mempengaruhi Perilaku Petani ...

Tabel 2. Hasil Pengujian Permodelan SEM Melibatkan Semua Indikator

\begin{tabular}{|c|c|c|c|c|c|c|c|}
\hline & & & Estimate & S.E. & C.R. & $\mathrm{P}$ & Label \\
\hline$Y$ & $<---$ & $\mathrm{x} 1$ & .067 & .095 & .698 & .485 & par_30 \\
\hline Y & $<---$ & $\mathrm{x} 2$ & .061 & .120 & .514 & .607 & par_31 \\
\hline Y & $<---$ & $\mathrm{x} 3$ & .109 & .112 & .972 & .331 & par_32 \\
\hline Z & $<---$ & $\mathrm{Y}$ & -.057 & .065 & -.871 & .384 & par_33 \\
\hline x1.8 & $<---$ & $\mathrm{x} 1$ & 1.000 & & & & \\
\hline $\mathrm{x} 1.7$ & $<---$ & $\mathrm{x} 1$ & .840 & .116 & 7.251 & $* * *$ & par_1 \\
\hline x1.6 & $<---$ & $\mathrm{x} 1$ & .807 & .112 & 7.227 & $* * *$ & par_2 \\
\hline$\times 1.5$ & $<---$ & $\mathrm{x} 1$ & .681 & .111 & 6.124 & $* * *$ & par_3 \\
\hline x1.4 & $<---$ & $\mathrm{x} 1$ & 1.044 & .127 & 8.220 & $* * *$ & par_4 \\
\hline x1.3 & $<---$ & $\mathrm{x} 1$ & .908 & .116 & 7.829 & $* * *$ & par_5 \\
\hline $\mathrm{x} 1.2$ & $<---$ & $\mathrm{x} 1$ & .891 & .115 & 7.769 & $* * *$ & par_6 \\
\hline x 1.1 & $<---$ & $\mathrm{x} 1$ & 1.006 & .127 & 7.944 & $* * *$ & par_7 \\
\hline $\mathrm{x} 2.8$ & $<---$ & $\mathrm{x} 2$ & 1.000 & & & & \\
\hline x2.6 & $<---$ & $\mathrm{x} 2$ & .999 & .158 & 6.316 & $* * *$ & par_8 \\
\hline $\mathrm{x} 2.5$ & $<---$ & $\mathrm{x} 2$ & .531 & .145 & 3.672 & $* * *$ & par_9 \\
\hline $\mathrm{x} 2.4$ & $<---$ & $\mathrm{x} 2$ & 1.025 & .161 & 6.370 & $* * *$ & par_10 \\
\hline $\mathrm{x} 2.2$ & $<---$ & $\mathrm{x} 2$ & 1.222 & .188 & 6.508 & $* * *$ & par_11 \\
\hline $\mathrm{x} 2.1$ & $<---$ & $\mathrm{x} 2$ & 1.340 & .197 & 6.819 & $* * *$ & par_12 \\
\hline x3.8 & $<---$ & $\mathrm{x} 3$ & 1.000 & & & & \\
\hline x3.7 & $<---$ & $\mathrm{x} 3$ & 1.235 & .162 & 7.620 & $* * *$ & par_13 \\
\hline x3.6 & $<---$ & $\mathrm{x} 3$ & 1.086 & .152 & 7.168 & $* * *$ & par_14 \\
\hline x3.5 & $<---$ & $\mathrm{x} 3$ & 1.131 & .153 & 7.386 & $* * *$ & par_15 \\
\hline x3.4 & $<---$ & $\mathrm{x} 3$ & 1.063 & .149 & 7.113 & $* * *$ & par_16 \\
\hline x3.3 & $<---$ & $\mathrm{x} 3$ & 1.304 & .159 & 8.204 & $* * *$ & par_17 \\
\hline x3.2 & $<---$ & $\mathrm{x} 3$ & 1.314 & .167 & 7.850 & $* * *$ & par_18 \\
\hline x3.1 & $<---$ & $\mathrm{x} 3$ & 1.176 & .160 & 7.357 & $* * *$ & par_19 \\
\hline y1.1 & $<---$ & $\mathrm{Y}$ & 1.000 & & & & \\
\hline y1.2 & $<---$ & Y & .870 & .069 & 12.616 & $* * *$ & par_20 \\
\hline y1.3 & $<---$ & Y & .982 & .066 & 14.952 & $* * *$ & par_21 \\
\hline y1.4 & $<---$ & $\mathrm{Y}$ & .936 & .068 & 13.710 & $* * *$ & par_22 \\
\hline y1.5 & $<---$ & $\mathrm{Y}$ & 1.002 & .066 & 15.269 & $* * *$ & par_23 \\
\hline y1.6 & $<---$ & Y & .977 & .065 & 14.939 & $* * *$ & par_24 \\
\hline Z1.1 & $<---$ & $\mathrm{Z}$ & 1.000 & & & & \\
\hline $\mathrm{Z} 1.2$ & $<---$ & $\mathrm{Z}$ & 1.120 & .088 & 12.726 & $* * *$ & par_25 \\
\hline Z1.3 & $<---$ & $\mathrm{Z}$ & 1.008 & .086 & 11.703 & $* * *$ & par_26 \\
\hline Z1.4 & $<---$ & $\mathrm{Z}$ & .870 & .086 & 10.115 & $* * *$ & par_27 \\
\hline Z1.5 & $<---$ & $\mathrm{Z}$ & 1.186 & .085 & 13.982 & $* * *$ & par_28 \\
\hline Z1.6 & $<---$ & $\mathrm{Z}$ & 1.007 & .086 & 11.727 & $* * *$ & par_29 \\
\hline
\end{tabular}

Karakteristik petani dominan dipengaruhi x1.4 atau pengalaman sebesar 1.044 satuan, kompetensi penyuluh dominan dipengaruhi oleh $\mathrm{x} 2.1$ atau kemampuan berkomunikasi sebesar 1.340 satuan, dan kompetensi pengurus kelompok tani dominan dipengaruhi oleh $\times 3.2$ atau kemauannya memberi contoh sebesar 1.314 satuan. Sementara faktor yang paling dominan membentuk perilaku petani adalah karena pelaksanaan OPRM sesuai dengan kebiasaan masyarakat tani (y1.5) sebesar 1.002, dan faktor yang paling dominan membentuk kemandirian petani adalah kemampuannya memiliki akses ke kredit usaha tani (z1.5) sebesar 1.186 satuan.

Peneliti lalu melakukan confirmantory factor analysis(CFA) terhadap karakteristik petani, kompetensi penyuluh dan kompetensi pengurus kelompok tani, untuk mencari model 
SEM lain yang dianggap sesuai dan dapat dipergunakan dalam penelitian perilaku petani peserta OPRM.

Uji CFA terhadap karakteristik petani menyimpulkan bahwa indikator keterampilan tidak masuk ke dalam kontruk permodelan SEM. Keterampilan (x1.5) memiliki nilai estimate di bawah 0,05 sehingga tidak memenuhi persyaratan pemodelan SEM (lihat tabel 3). Diduga, indikator keterampilan kurang mempengaruhi perilaku petani dalam menerima atau menolak keberadaan OPRM.

Uji CFA terhadap kompetensi penyuluh yang melibatkan delapan indikator pembentuk konstruk, juga memperlihatkan adanya tiga indikator yang diduga tidak membentuk konstruk kompetensi penyuluh. Yakni sistematis dalam penyampaian program, penguasaan materi program, serta mampu mengefisiensi waktu. Diduga penyuluh kurang menguasai program dan tidak sistematis saat menyampaikan program ke petani sehingga sama sekali tidak akan mampu mengefisiensi waktu petani (lihat tabel 4).

Uji CFA yang dilakukan terhadap kompetensi pengurus kelompok tani, perilaku petani dan kemandirian petani, sama sekali tidak memperlihatkan adanya indikator yang memiliki nilai estimate di bawah 0,5. Artinya, semua indikator yang dipergunakan dalam penelitian sudah mewakili konstruk kompetensi pengurus kelompok tani, perilaku petani dan kemandirian petani.

Semua indikator yang dinyatakan telah mewakili semua konstruk yang dipergunakan dalam penelitian, diikut sertakan untuk pengujian model secara lengkap agar dapat dijelaskan pengaruh dari karakteristik petani, kompetensi penyuluh, dan kompetensi pengurus kelompok tani terhadap perilaku petani dalam mengambil keputusan serta kemandirian petani. Pengujian model dilakukan menggunakan persamaan structural (structural equation modeling) sebagaimana dapat dilihat pada gambar 3.

Permodelan SEM yang dibangun memperlihatkan nilai GFI, TLI, dan CFI berada antara rentang besar dari 0,8 dan kecil dari 0,9 , atau model dikatakan marginal fit. Sementara nilai RMSEA dan CMIN/DF sudah memenuhi syarat permodelan SEM, meski model yang dibangun over identified dengan nilai probabilitas masih 0,000 .

Tabel 3. Hasil Uji CFA Karakteristik Petani

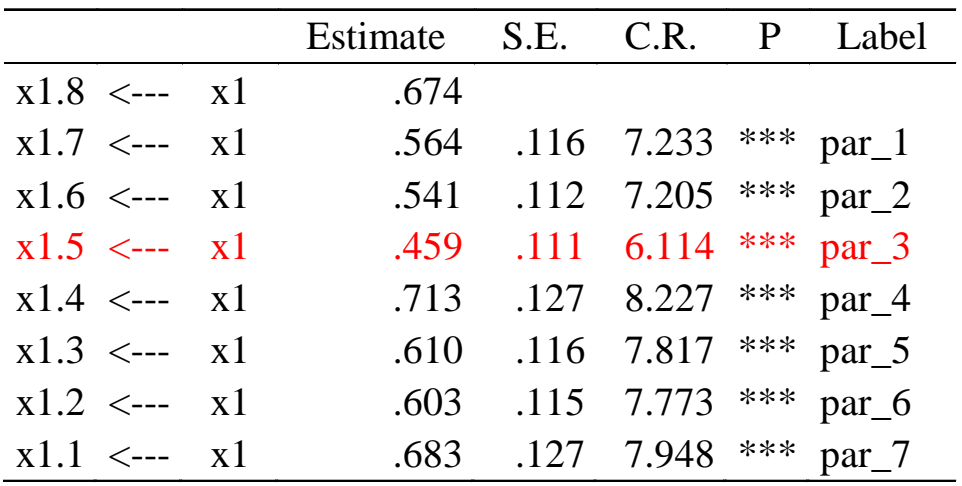

Tabel 4. Hasil Uji CFA Kompetensi Penyuluh

\begin{tabular}{|c|c|c|c|c|c|c|}
\hline & & & Estimate & S.E. & C.R. & P Label \\
\hline $\mathrm{x} 2.8$ & $<--$ & $\mathrm{x} 2$ & 0.564 & & & \\
\hline$x 2.7$ & $<---$ & $\mathrm{x} 2$ & 0.351 & 0.149 & 4.144 & *** par_1 \\
\hline $\mathrm{x} 2.6$ & $<--$ & $x 2$ & 0.51 & 0.152 & 5.947 & *** par_2 \\
\hline $\mathrm{x} 2.5$ & $<---$ & $\mathrm{x} 2$ & 0.406 & 0.157 & 4.555 & *** par_3 \\
\hline $\mathrm{x} 2.4$ & $<---$ & $x 2$ & 0.571 & 0.158 & 6.387 & $* * *$ par_4 \\
\hline $\mathrm{x} 2.3$ & $<---$ & $x 2$ & 0.388 & 0.154 & 4.442 & *** par_5 \\
\hline $\mathrm{x} 2.2$ & $<---$ & $x 2$ & 0.671 & 0.179 & 6.622 & *** par_6 \\
\hline $\mathrm{x} 2.1$ & $<---$ & $\mathrm{x} 2$ & 0.731 & 0.186 & 6.954 & $* * *$ par_7 \\
\hline
\end{tabular}




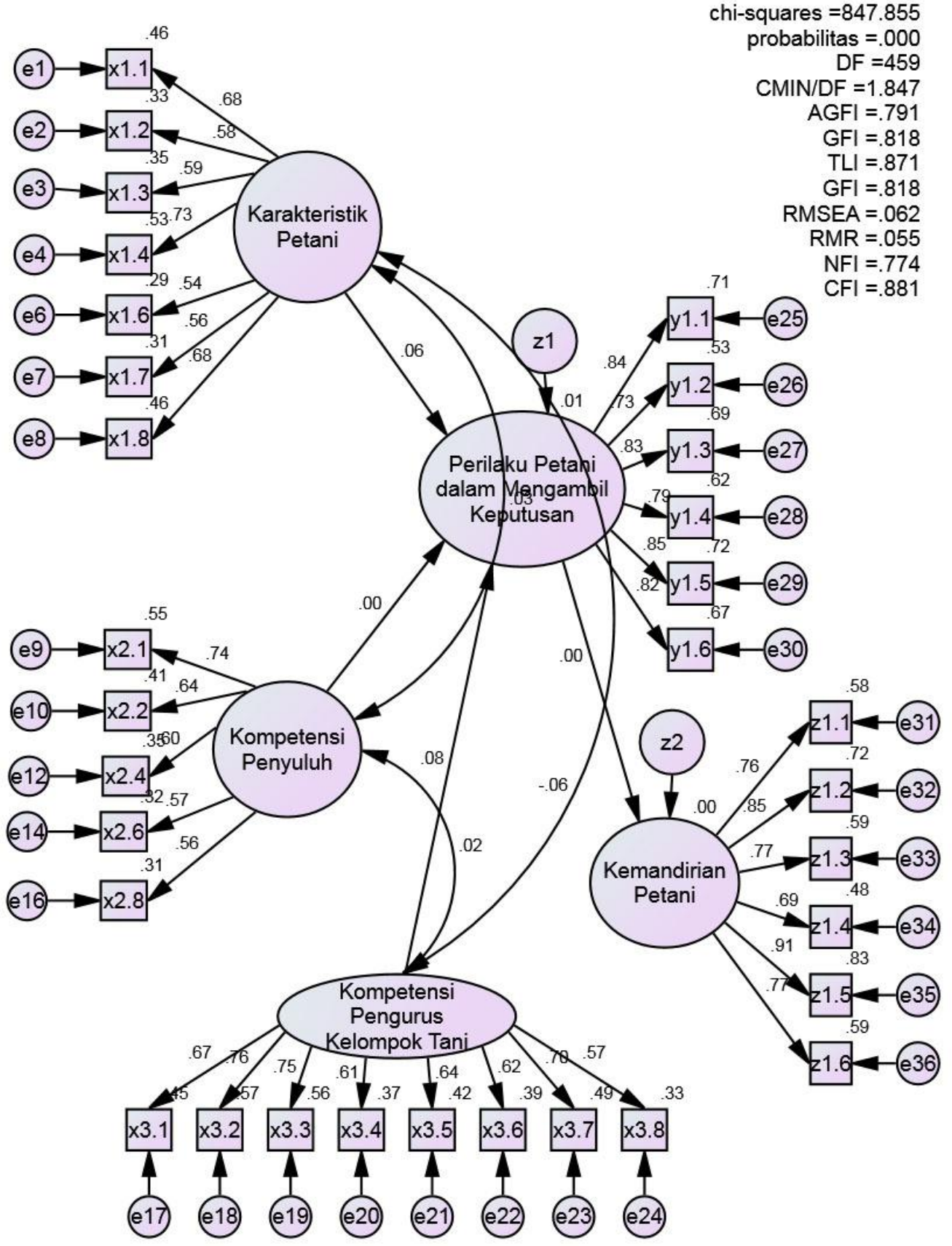

Gambar 3. Permodelan SEM Melibatkan Indikator Pembangun Konstruk

Permodelan SEM yang dibangun sebelumnya masih mengandung nilai negatif sehingga dilakukan modifikasi menggunakan modifikasi indices padaoutput analisa, untuk mendapatkan nilai yang memenuhi syarat uji kelayakan seperti gambar 4.

Model SEM modifikasi yang dibangun masih over identified dengan degree of freedom 440 atau $>68$ yang disebabkan oleh besarnya jumlah informasi yang diperlukan dari jumlah parameter yang diamati. Meski pun begitu, beberapa nilai yang dihasilkan sudah dapat memenuhi syarat uji kelayakan yang diinginkan.

Permodelan SEM yang diajukan menyimpulkan, karakteristik petani akan mempengaruhi petani sebesar 0,91 satuan, dengan indikator yang paling dominan membentuk karakteristik petani adalah tingkat subsitensi sebesar 0,732 satuan, serta motivasi berusaha sebesar 0,609 satuan seperti tabel 5 . 
Nuke F., Fajar R. Dan Roza Y. : Faktor-Faktor Yang Mempengaruhi Perilaku Petani ...

Variabel kompetensi penyuluh dengan perilaku petani dalam pengambilan keputusan hanya bernilai 0,16 satuan, dan konstruk yang paling dominan mempengaruhi variabel kompetensi penyuluh adalah kemampuan penyuluh untuk memahami petani sebesar 0,650 satuan, serta kemauan penyuluh untuk memberi semangat kepada petani sebesar 0,613 satuan.

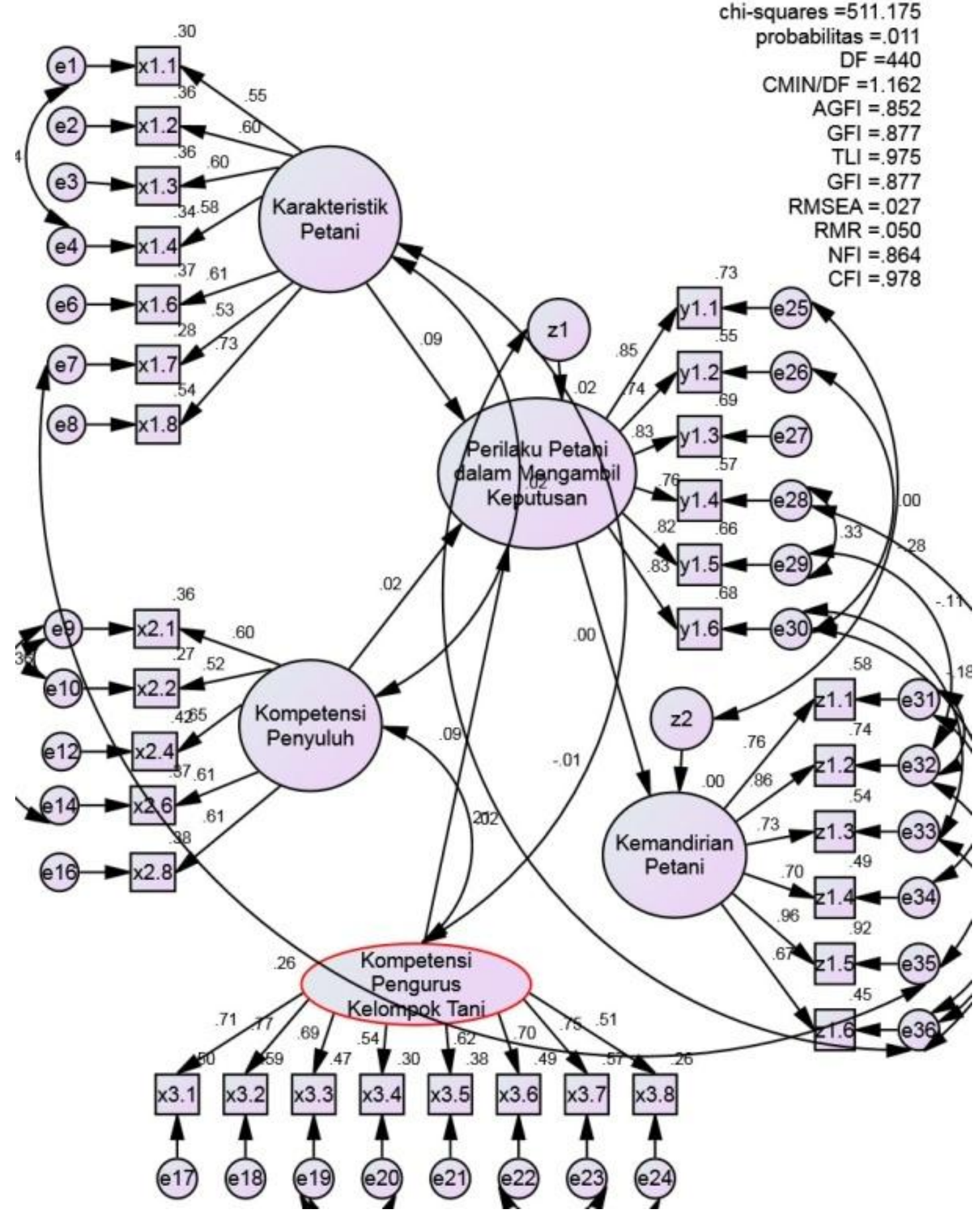

Gambar 4. Permodelan SEM Dengan Modifikasi Indices 
Nuke F., Fajar R. Dan Roza Y. : Faktor-Faktor Yang Mempengaruhi Perilaku Petani ...

Tabel 5. Hasil Analisis Model SEM yang Sesuai

\begin{tabular}{|c|c|c|c|c|c|c|c|}
\hline Y1 & $<---$ & X1 & 0.091 & 0.089 & 1.191 & 0.234 & par_28 \\
\hline Y1 & <--- & $\mathrm{X} 2$ & 0.016 & 0.113 & 0.193 & 0.847 & par_29 \\
\hline Y1 & $<---$ & X3 & 0.09 & 0.121 & 1.236 & 0.216 & par_30 \\
\hline Y2 & $<---$ & Y1 & 0.001 & & & & \\
\hline x 1.8 & $<---$ & X1 & 0.732 & & & & \\
\hline x1.7 & $<---$ & $\mathrm{X} 1$ & 0.534 & 0.108 & 6.586 & $* * *$ & par_1 \\
\hline x1.6 & $<---$ & $\mathrm{X} 1$ & 0.609 & 0.107 & 7.832 & $* * *$ & par_2 \\
\hline x1.4 & $<---$ & $\mathrm{X} 1$ & 0.58 & 0.11 & 7.099 & $* * *$ & par_3 \\
\hline x1.3 & $<---$ & $\mathrm{X} 1$ & 0.599 & 0.108 & 7.419 & $* * *$ & par_4 \\
\hline $\mathrm{x} 1.2$ & $<--$ & $\mathrm{X} 1$ & 0.601 & 0.11 & 7.413 & $* * *$ & par_5 \\
\hline x1.1 & $<---$ & $\mathrm{X} 1$ & 0.551 & 0.111 & 6.842 & $* * *$ & par_6 \\
\hline $\mathrm{x} 2.8$ & $<---$ & $\mathrm{X} 2$ & 0.613 & & & & \\
\hline$x 2.6$ & $<---$ & $\mathrm{X} 2$ & 0.608 & 0.166 & 6.05 & $* * *$ & par_7 \\
\hline $\mathrm{x} 2.4$ & $<---$ & $\mathrm{X} 2$ & 0.65 & 0.181 & 5.925 & $* * *$ & par_8 \\
\hline $\mathrm{x} 2.2$ & $<---$ & $\mathrm{X} 2$ & 0.524 & 0.161 & 5.328 & $* * *$ & par_9 \\
\hline $\mathrm{x} 2.1$ & $<---$ & $\mathrm{X} 2$ & 0.6 & 0.171 & 5.658 & $* * *$ & par_10 \\
\hline x3.8 & <--- & X3 & 0.509 & & & & \\
\hline x3.7 & $<---$ & X3 & 0.753 & 0.212 & 7.022 & $* * *$ & par_11 \\
\hline x3.6 & $<---$ & X3 & 0.697 & 0.199 & 6.833 & $* * *$ & par_12 \\
\hline x3.5 & $<---$ & X3 & 0.619 & 0.187 & 6.598 & $* * *$ & par_13 \\
\hline x3.4 & $<---$ & X3 & 0.544 & 0.177 & 6.086 & $* * *$ & par_14 \\
\hline x3.3 & $<---$ & X3 & 0.686 & 0.17 & 7.878 & $* * *$ & par_15 \\
\hline x3.2 & $<--$ & X3 & 0.77 & 0.212 & 7.291 & $* * *$ & par_16 \\
\hline x3.1 & $<---$ & $\mathrm{X} 3$ & 0.708 & 0.2 & 7.006 & $* * *$ & par_17 \\
\hline y1.1 & $<---$ & Y1 & 0.853 & & & & \\
\hline y1.2 & $<---$ & Y1 & 0.739 & 0.068 & 12.445 & $* * *$ & par_18 \\
\hline y1.3 & $<---$ & Y1 & 0.832 & 0.065 & 14.921 & $* * *$ & par_19 \\
\hline y1.4 & $<---$ & Y1 & 0.758 & 0.069 & 12.806 & $* * *$ & par_20 \\
\hline y1.5 & $<---$ & Y1 & 0.815 & 0.066 & 14.553 & $* * *$ & par_21 \\
\hline y1.6 & $<---$ & Y1 & 0.825 & 0.065 & 14.943 & $* * *$ & par_22 \\
\hline z1.1 & $<---$ & Y2 & 0.761 & & & & \\
\hline $\mathrm{z} 1.2$ & $<---$ & Y2 & 0.858 & 0.098 & 11.585 & $* * *$ & par_23 \\
\hline z1.3 & $<---$ & Y2 & 0.733 & 0.084 & 11.187 & $* * *$ & par_24 \\
\hline z1.4 & $<---$ & Y2 & 0.703 & 0.068 & 12.932 & $* * *$ & par_25 \\
\hline z1.5 & $<---$ & $\mathrm{Y} 2$ & 0.961 & 0.082 & 14.596 & $* * *$ & par_26 \\
\hline z1.6 & $<---$ & Y2 & 0.672 & 0.085 & 10.386 & $* * *$ & par_27 \\
\hline
\end{tabular}

Tabel 6. Indeks Pengujian Kelayakan Structural Equation Modeling

\begin{tabular}{llll}
\hline Goodness of fit indeks & Cut-off Value & Hasil analisis & Evaluasi model \\
\hline Chi-square & $<260,992$ & 511.175 & Out Fit \\
Probability & $\geq 0.05$ & 0.011 & Fit \\
RMSEA & $\leq 0.08$ & 0.027 & Fit \\
GFI & $\geq 0.90$ & 0.877 & Marginal Fit \\
AGFI & $\geq 0.80$ & 0.852 & Marginal Fit \\
CMIN/DF & $\leq 2.00$ & 1.162 & Fit \\
TLI & $\geq 0.90$ & 0.975 & Fit \\
CFI & $\geq 0.90$ & 0.978 & Fit \\
\hline
\end{tabular}


Nuke F., Fajar R. Dan Roza Y. : Faktor-Faktor Yang Mempengaruhi Perilaku Petani ...

Tabel 7. Analisis Faktor Dengan Pengelompokkan Atas Lima Variabel

Rotated Component Matrix ${ }^{a}$

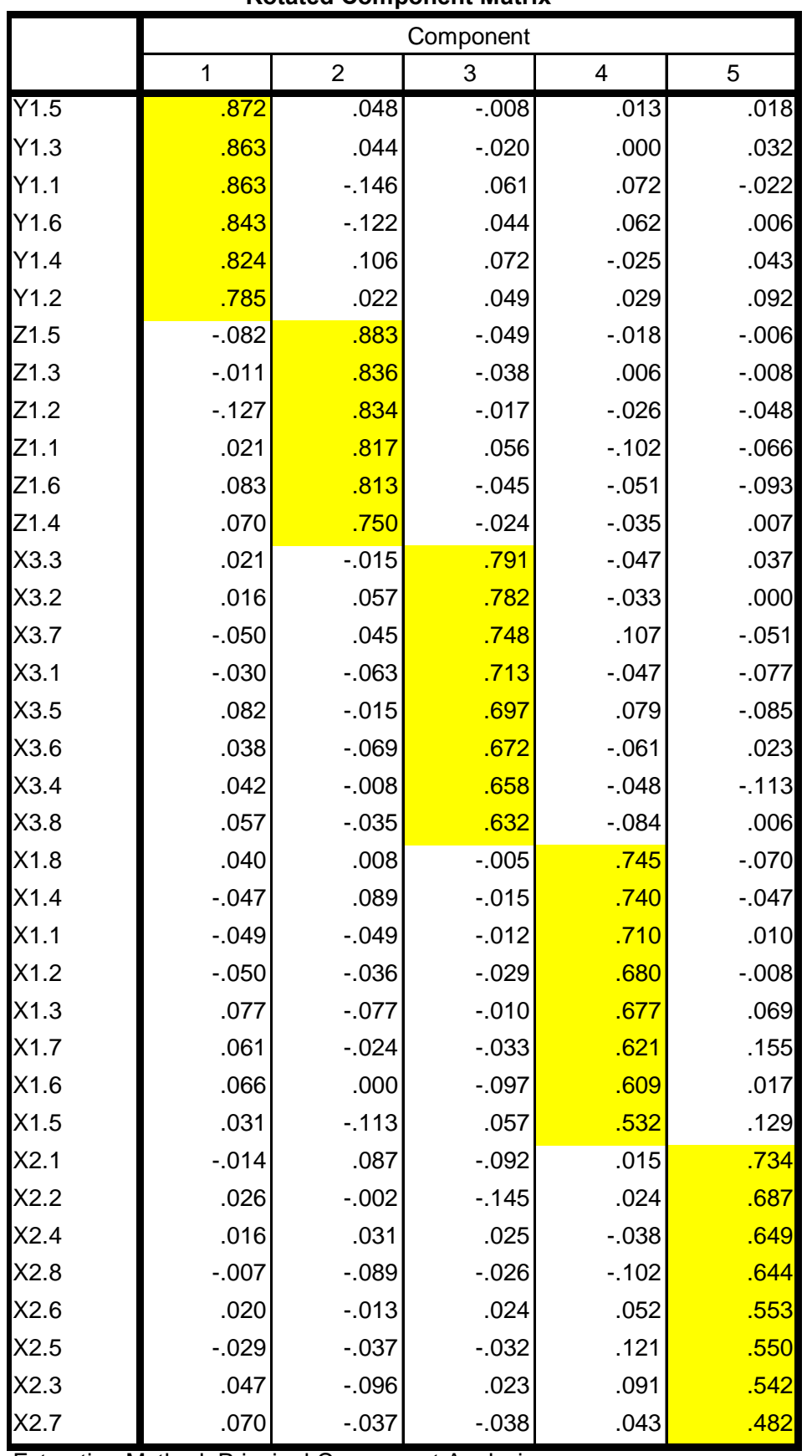

Extraction Method: Principal Component Analysis.

a. Rotation converged in 5 iterations.

Sementara kompetensi pengurus kelompok tani dengan perilaku petani dalam pengambilan keputusan adalah 0,90 satuan, di mana indikator yang paling dominan memengaruhi kompetensi pengurus kelompok tani adalah mau memberikan contoh 0,770 satuan, dan selalu bersikap jujur serta terbuka 0,753 satuan. Hasil uji kelayakan terhadap model yang dibangun dapat dilihat pada tabel 6.

Persamaan struktural 1 untuk permodelan SEM yang telah mengalami modifikasi pada output analisanya yang dibentuk dalam persamaan adalah Perilaku Petani $=0,91 \mathrm{KP}+0,168 \mathrm{KPE}+0,90 \mathrm{KPK}+$ error term, di mana KP adalah karakteristik petani, 
KPE adalah kompetensi penyuluh, dan KPK adalah kompetensi pengurus kelompok tani.Sementara kemandirian petani hanya dipengaruhi 0,001 perilaku petani dalam mengambil keputusan, dengan persamaan struktural 2 menjadi Kemandirian Petani $=$ 0,001Perilaku Petani+error term.

Indikator yang paling dominan membentuk kemandirian petani adalah kemampuan petani untuk memiliki akses ke kredit usaha tani $(0,961$ satuan), dan indikator yang paling dominan membentuk perilaku petani adalah menganggap OPRM lebih baik dari program bercocok tanam padi konvensional ( 0,853 satuan).

\section{Faktor Analisis}

Uji faktor analisis dilakukan untuk melihat pengelompokan dari indikator-indikator yang dipergunakan dalam penelitian agar dapat diketahui kesesuaian penempatan dari indikator-indikator yang diajukan dengan awal permodelan SEM yang dibangun. Setelah dilakukan pengujian menggunakan SPSS, maka diketahui bahwa indikator-indikator dari pembentuk variabel sudah mengelompok ke dalamvariable permodelan SEM yang peneliti bangun (lihat tabel 7).

Indikator pembentuk karakteristik petani, $\mathrm{x} 1$, sudah sesuai penempatannya, atau memang dibentuk oleh umur, pendidikan formal, luas usaha tani, pengalaman, keterampilan, motivasi berusaha, modal usaha tani dan tingkat subsitensi. Indikator pembentuk kompetensi penyuluh, x2, juga sudah sesuai dengan penempatannya, atau dapat diukur dengan kemampuan berkomunikasi, daya adaptasi, sistematis dalam penyampaian program, kemauan untuk memahami keinginan petani, penguasaan terhadap materi program, pengalaman, kemampuan untuk mengefisiensi waktu serta kemauan memberi dukungan semangat kepada petani.

Kompetensi pengurus kelompok tani, $\mathrm{x}$, ternyata juga dibentuk olehkemampuan menyebarluaskan informasi, memberi contoh, menyarankan pelaksanaan program, memengaruhi anggota kelompok, memberi semangat, selalu bersikap jujur dan terbuka, serta selalu melibatkan anggota dalam pengambilan keputusan.

\section{KESIMPULAN}

Perilaku petani dipengaruhi oleh umur, tingkat pendidikan, luas usaha tani, pengalaman, motivasi berusaha, tingkat subsitensi, modal usaha, kompetensi penyuluh (kemampuan komunikasi, adaptasi, memahami keinginan petani, berpengalaman serta mau memberi semangat kepada petani), kompetensi pengurus kelompok tani (kemampuan menyebarluaskan informasi, memberi contoh, menyarankan pelaksanaan program, mempengaruhi anggota kelompok, memberi semangat, selalu bersikap jujur dan terbuka, serta selalu melibatkan anggota dalam pengambilan keputusan).

\section{DAFTAR PUSTAKA}

Adiputra, I Gede Setiawan, 2012. FaktorFaktor yang Mempengaruhi Anggota Subak Mengadopsi System of Rice Intensification (SRI) Di 7 Kabupaten Di Provinsi Bali. Sekolah Pasca Sarjana Institut Pertanian Bogor. Bogor, Indonesia.

Andrianto dan Taufiq,T. 2014. Pengantar Ilmu Pertanian, Agraris, Agrobisnis, Agroindustri dan Agroteknologi. Global Pustaka Utama. Jogjakarta, Indonesia

Badan Pusat Statistik Dalam Angka, 2013. BPS Pekanbaru. Pekanbaru, Indonesia.

Bank Indonesia Dalam Angka, 2013. BI Pekanbaru. Pekanbaru, Indonesia.

Haryono, Siswoyo dan Wardoyo, P. 2012. Structural Equation Modelling Untuk Penelitian Manajemen Menggunakan Amos 18.00. PT Intermedia Personalia Utama. Jawa Barat, Indonesia.

Latan, H, 2013. Model Persamaan Struktural Teori dan Impelementasi AMOS 21.0. Alphabeta. Bandung, Indonesia

Mardikanto, T dan Soebianto, P. 2013. Pemberdayaan Masyarakat Dalam Perspektif Kebijakan Publik. Alfabeta. Bandung, Indonesia

OPRM, 2013. Dinas Tanaman Pangan dan Hortikultura Provinsi Riau. Riau, Indonesia. 